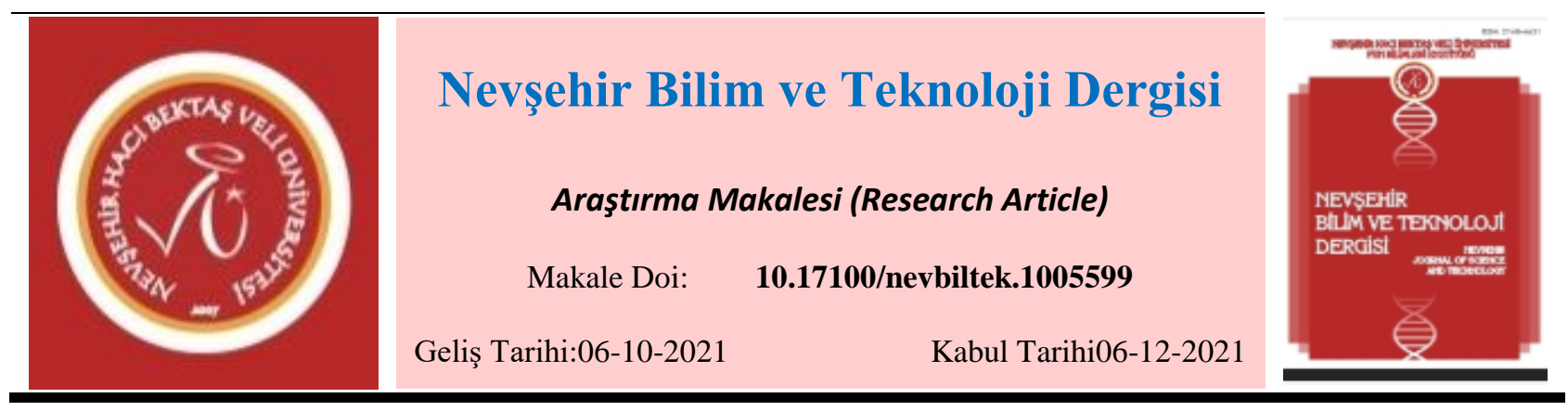

\title{
Co-pyrolysis of Heavy Aromatic Waste and Polystyrene: Analysis of Liquid Product via GC- MS
}

\author{
Mesut ARDIÇ ${ }^{1}$, Gamze ÖZÇAKIR ${ }^{2, *}$, Ali KARADUMAN ${ }^{3}$ \\ ${ }^{1}$ Ankara University, Engineering Faculty, Department of Chemical Engineering, Ankara, Turkey \\ ORCID ID: 0000-0001-8252-9511 \\ ${ }^{2}$ Bilecik Şeyh Edebali University, Engineering Faculty, Department of Chemical Engineering, Bilecik, Turkey \\ ORCID ID: 0000-0003-0357-4176 \\ ${ }^{3}$ Ankara University, Engineering Faculty, Department of Chemical Engineering, Ankara, Turkey \\ ORCID ID: 0000-0003-1061-8288
}

\begin{abstract}
Plastic wastes form $18.46 \%$ of total municipal solid wastes in 2018 around the world. Heavy hydrocarbons occur as the waste of refinery processes. In this study co-pyrolysis of waste polystyrene foam (PS) and heavy aromatic waste (HAW) which can be accepted as a derivative of an oily sludge was carried out for the first time in literature. It was aimed to investigate the effect of temperature $\left(420,450,480{ }^{\circ} \mathrm{C}\right)$ and mixing ratio $(1 / 5,3 / 5,1 / 1)$ on liquid product yield and compound distribution in the pyrolytic liquids. Whole experiments were done in semi-batch reactor configuration under nitrogen atmosphere. Gas chromatography-Mass spectrometry (GC-MS) was utilized to analyze the pyrolytic liquids. At $480{ }^{\circ} \mathrm{C}$ it was obtained maximum liquid yield was $87.24 \%$ in 1/5 HAW/PS feedstock ratio. Compared to pure PS pyrolysis, it was achieved relatively low styrene, toluene yield. However, yields of ethylbenzene and cumene increased with HAW added to the feed. Naphthalene was not detected in the liquid of PS pyrolysis. Maximum naphthalene yield was taken as $12.71 \%$ at $480{ }^{\circ} \mathrm{C}$ with a $1 / 5 \mathrm{HAW} / \mathrm{PS}$ feedstock ratio.
\end{abstract}

Keywords: Co-pyrolysis, GC-MS, heavy aromatic waste, plastic wastes, polystyrene

\section{Ağır Aromatik Atık ve Polistirenin Eş-pirolizi: Sıvı Ürünün GC-MS ile Analizi}

$\ddot{O} \mathbf{z}$

Plastik atıklar dünya çapında 2018 yılındaki toplam kentsel katı atıkların \%18,46’sını oluşturur. Ağır hidrokarbonlar rafineri proseslerinin atı̆̆ı olarak meydana gelir. Bu çalışmada, literatürde ilk defa atık polistiren köpük (PS) ve bir petrol çamuru türevi olan ağır aromatik atığın (HAW) eş-pirolizi yürütülmüştür. Sıcaklık $\left(420,450,480{ }^{\circ} \mathrm{C}\right)$ ve karıştırma oranının $(1 / 5,3 / 5,1 / 1)$ sıvı ürün verimi ve pirolitik sıvıların bileşik dağılımı üzerindeki etkisini incelemek amaçlanmıştır. Tüm deneyler yarı-kesikli reaktör konfigürasyonunda azot atmosferi altında yapılmıştır. Gaz kromatografi-Kütle spektrometresi (GC-MS) pirolitik sıvıları analiz etmek için kullanılmıştır. $480{ }^{\circ} \mathrm{C}$ 'de $1 / 5 \mathrm{HAW} / \mathrm{PS}$ besleme oranında maksimum sıvı verimi \% $\% 7.24$ olarak elde edilmiştir. Saf PS pirolizi ile karşılaştırıldığında, nispeten düşük stiren ve toluene verimi edinilmiştir. Bununla birlikte, etilbenzen ve kümen verimleri beslemeye HAW katılmasıyla artmıştır. Naftalin PS pirolizinin sıvısında tespit edilmemiştir. Maksimum naftalin verimi $480{ }^{\circ} \mathrm{C}$ 'de $1 / 5$ HAW/PS besleme oranında \% 12,71 olarak alınmıştır.

Anahtar Kelimeler: Eş-piroliz, GC-MS, ağır aromatik atık, plastik atıklar, polistiren

\footnotetext{
* Corresponding author: gamze.ozcakir@bilecik.edu.tr
} 


\section{Introduction}

Municipal solid waste (MSW) means that a mixture of solid wastes which is thrown by people in the urban and rural areas [1]. According to the World Bank, it is expected that the amount of municipal solid waste will be up 3.4 billion tonnes by 2050 [2]. According to the United States Environmental Protection Agency, 146.1 million tonnes of MSW was landfilled in 2018 around the world. Plastic wastes form $18.46 \%$ of this value [3]. The reason for this high amount originates from several advantages of plastics. Plastics have thermal and electrical insulation properties, hygienic for food packaging, resistance against chemicals and water, low weight for reducing transportation costs, durability, and longevity feature. But, they have some disadvantages too. Stabilizers, colorants, and phthalates are harmful materials that are used in plastic production. They occur as a threat to human life. In an environmental view, plastics are non-degradable, their breaking down can take a long time. Besides that, landfilling of plastic wastes occur a problem [4]. Recycling plastic wastes can occur in three ways: mechanical recycling, energy recovery, and chemical recovery. In the mechanical recycling route, it is benefited from expensive machines. In the energy recovery route, carbon dioxide $\left(\mathrm{CO}_{2}\right)$ which is the main greenhouse gas is released. Thus, the chemical recovery route comes to the forefront [5].

Pyrolysis is by far the most studied chemical recovery technique compared to liquefaction and gasification. In the pyrolysis technique, liquid fuel, solid residue, and gas products are obtained from several materials at the same time under an oxygen-free atmosphere. The pyrolytic product distribution majorly depends on the reaction temperature, heating rate, residence time, and reactor type [6].

Polystyrene is a thermally and mechanically stable material uses in food packaging, electronic, medical, and toy sectors [5]. From past to present, polystyrene pyrolysis in several reactor configurations has taken place in literature. Karaduman et al. (2001) carried out polystyrene pyrolysis in a free-fall reactor under vacuum to investigate the effect of particle size and temperature on liquid product yield and composition. They obtained a maximum liquid yield of $32 \%$ at $750{ }^{\circ} \mathrm{C}$. At this temperature toluene, styrene, naphthalene yields were nearly 10, 20, $50 \%$ respectively. They found also that large particle size $(300-212 \mu \mathrm{m})$ maximized the liquid yield at $825^{\circ} \mathrm{C}$ [7]. Nisar et al. (2019) investigated the effect of reaction time and temperature on the liquid yield of polystyrene by using a pyrex glass reactor. They found that 410 ${ }^{\circ} \mathrm{C}$ and 70 min at which liquid yield was almost $90 \%$ were the ideal reaction conditions. Styrene/ethylbenzene yield at this condition was $35 \%$ [8]. Park et al. (2020) studies two-step pyrolysis set up which included an auger reactor and a fluidized reactor. They aimed to increase benzene-toluene-ethyl benzene-xylene (BTEX) yield in the liquid product. They obtained a maximum BTEX yield of $26 \%$ at $780{ }^{\circ} \mathrm{C}$ in a fluidized bed reactor and $300^{\circ} \mathrm{C}$ in an auger reactor. They found liquid yield as $86 \%$ under these conditions [9]. In the last years, researchers have studied on co-pyrolysis of polystyrene with various materials such as low-rank coal [10], pinewood [11], sawdust [12], grape seeds [13], macroalgae [14], rubber seed [15], coffee grounds [16], other polymers [17] to determine synergistic effect between them.

Oily sludge is an industrial waste. It can occur during the production, refining, storage, and transportation of petroleum. Oily sludge is an emulsion that consists of a solid and liquid part. Because it includes components like heavy metals and polycyclic aromatic hydrocarbons (PAHs), oily sludge is accepted as hazardous and toxic for human health and the environment [18]. The hydrocarbon content of oily sludge can be between 5 and $86 \%$ by mass. It can be possible to find anthracene, alkanes, cycloalkanes, benzene, toluene, xylenes, naphthalene, phenols in oily sludge [19]. There are several methods to dispose of oily sludge such as freeze/thaw method, ultrasonic/microwave irradiation, water/thermochemical cleaning, solvent extraction, centrifugation, biological treatment, advanced oxidation, solidification/stabilization, landfill, and thermochemical methods. Thermochemical methods which were used in oily sludge treatment are hydrothermal liquefaction, gasification, pyrolysis, incineration, thermal desorption. Hydrothermal liquefaction requires high temperature $\left(200-600^{\circ} \mathrm{C}\right)$ and pressures $(5-40 \mathrm{MPa})$, In thermal desorption which was seemed like the first stage of pyrolysis recovery of all hydrocarbons don't occur completely. In gasification, syngas product has 
Nevşehir Bilim ve Teknoloji Dergisi (2021), 10(2) 92-100

high impurity. In incineration, harmful gas emissions and high operating costs are disadvantages. In comparison with the other thermochemical methods, pyrolysis provides to obtain maximum oil recovery and less pollutant emission by far [20].

In refinery processes, components in crude oil are separated with respect to their boiling points. Heavy hydrocarbons forms as the waste of this process. They are converted to gas, naphtha, and light cycle oil via further treatments like catalytic cracking, alkylation, and hydrogenation [21]. To the best of our knowledge, there is no study about heavy aromatic waste which can be accepted as a derivative of an oily sludge and polystyrene pyrolysis in literature. This study it was aimed to investigate the effect of temperature and mixing ratio on liquid product yield and compound distribution in the liquid of these two materials.

\section{Material and methods}

Heavy aromatic waste (HAW) was supplied from a Turkish petrochemical company, TÜPRAŞ. Waste polystyrene foam (PS) was used in experiments. The experimental set-up was the same as our previous research [5]. Pyrolytic experiments were carried out pyrex glass reactor in the homemade ceramic furnace under a nitrogen atmosphere. The pyrolytic setup was shown in Fig. 1. The temperature was changed between $420-480{ }^{\circ} \mathrm{C}$ with $30^{\circ} \mathrm{C}$ step size. The residence time was selected as $60 \mathrm{~min}$. The weight percentage of HAW/PS was 1/5, 3/5, 1/1. Liquid product yield was calculated as follows:

Liquid product yield $(\%)=$ [collected liquid after the experiment, g/initial feedstock amount in the reactor, $\mathrm{g}$ ]*100

Liquid products were collected by using a phase separator and sent to Gas Chromatography-Mass Spectroscopy (GC-MS) equipment. The brand and model of GC-MS were ThermoFinnigan and DSQ-250 respectively. Rtx-5 capillary column was used in the equipment. Helium whose flow rate was $0.7 \mathrm{~mL} / \mathrm{min}$ was utilized as carrier gas. The temperature program of the column was started at $50{ }^{\circ} \mathrm{C}$. The column stayed at this temperature for $5 \mathrm{~min}$. Then, the column temperature was increased by $270{ }^{\circ} \mathrm{C}$ with a $5{ }^{\circ} \mathrm{C} /$ min heating rate. And finally, the column was kept at this temperature for $20 \mathrm{~min}$.

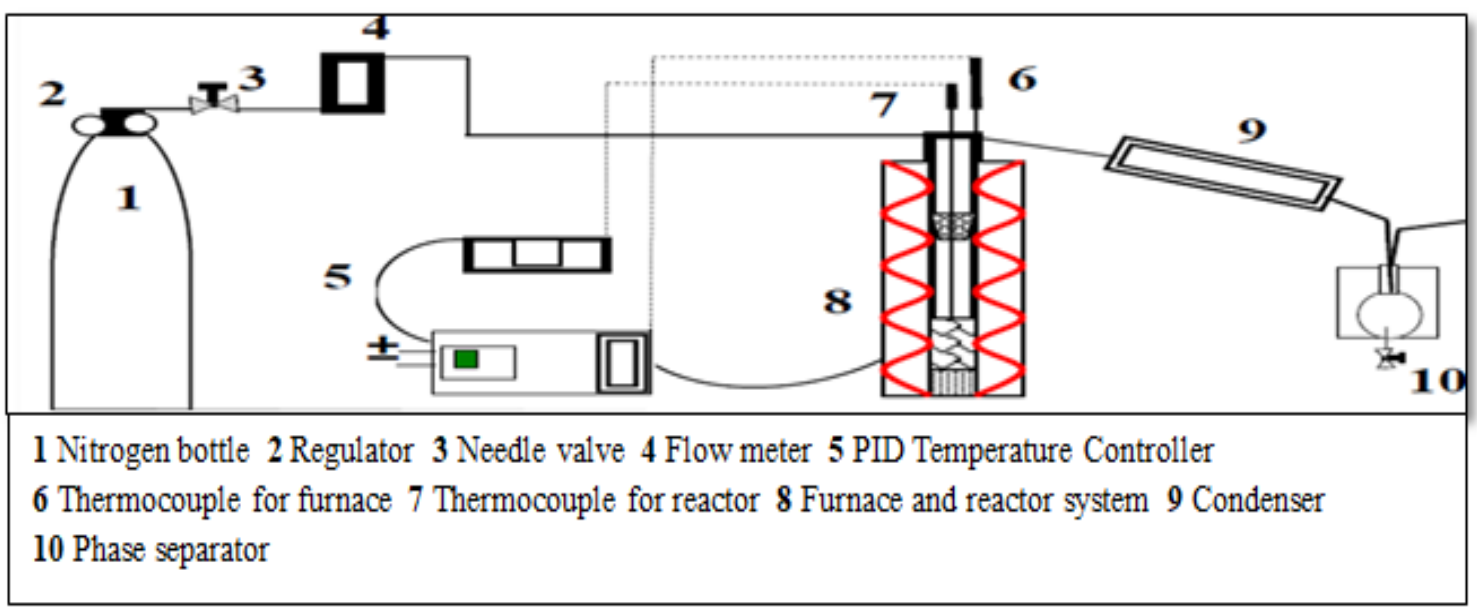

Figure 1. Experimental pyrolysis set-up [5] 


\section{Results and discussion}

As shown in Fig. 2, it was found that liquid yield affected both temperature and feedstock composition. At 420 ${ }^{\circ} \mathrm{C}$ it was obtained maximum liquid yield was $78.67 \%$ in $1 / 5$ feedstock ratio. This matter did not change at other temperatures. $480{ }^{\circ} \mathrm{C}$ and $1 / 5$ feedstock ratio formed the optimum condition for liquid yield. At this condition, the liquid yield was found as $87.24 \%$. It can be also said that there was no liquid yield difference between 480 and $450{ }^{\circ} \mathrm{C}$. Then, it was not tried further temperatures to investigate liquid yield. At $480{ }^{\circ} \mathrm{C}$ PS pyrolytic liquid yield was found as $87.02 \%$ which was lower than co-pyrolysis yield.

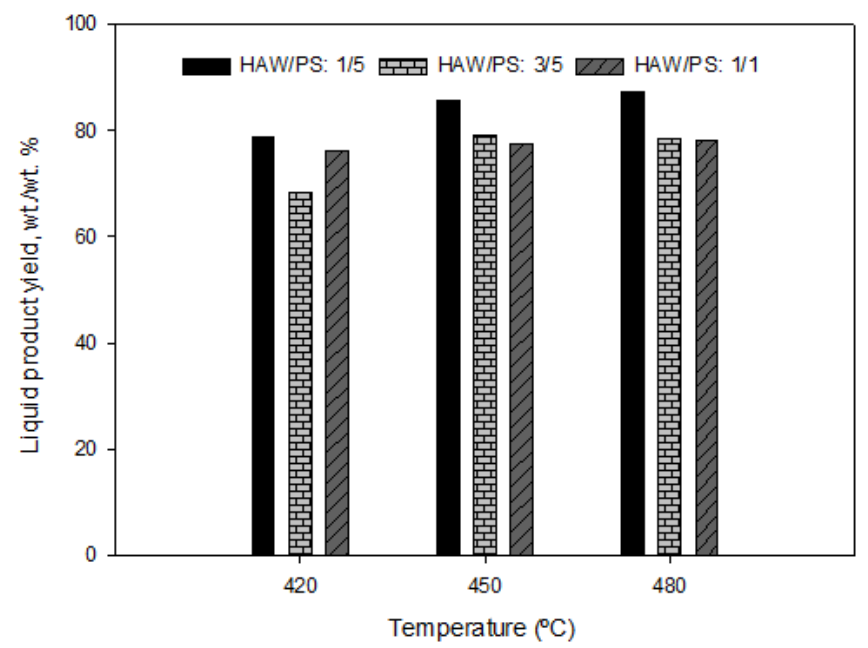

Figure 2. Changing in liquid yield with temperature and feedstock ratio

At the optimum condition, liquid product composition was investigated comprehensively and was compared to PS pyrolytic liquid at $480^{\circ} \mathrm{C}$. The Chromatogram of PS pyrolytic liquid was shown in Fig. 3. Determined compounds in pyrolytic liquid of PS were given in Table 1. As shown in Table 1, the liquid product of polystyrene pyrolysis formed mainly C7-C17 hydrocarbons. There were some components whose peak areas were bigger than others. For example, Styrene yield was found as $43.74 \%$. Besides that, ethylbenzene and toluene yields were obtained as 4.16 and $6.15 \%$ respectively. These components can be occurred because of further decomposition of styrene at $480{ }^{\circ} \mathrm{C}$ [8].

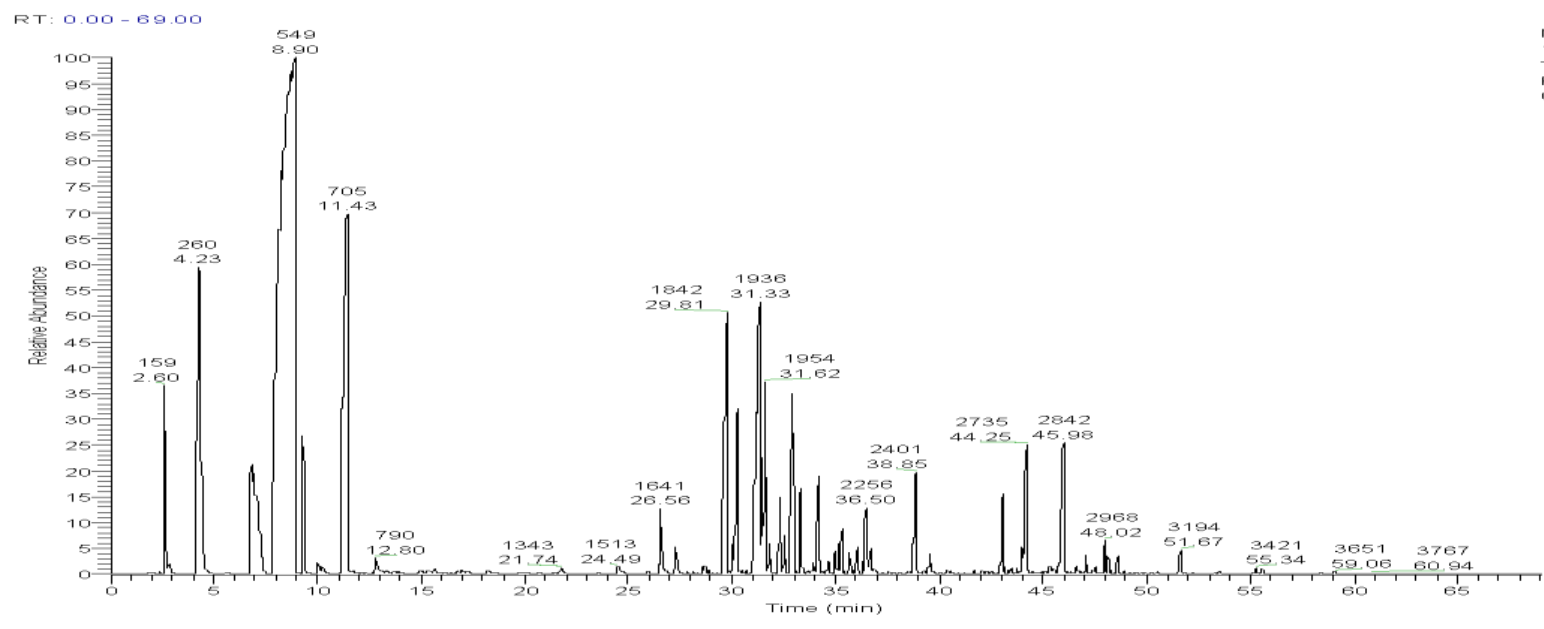

Figure 3. Chromatogram of the liquid product of PS at $480{ }^{\circ} \mathrm{C}$ 
Nevşehir Bilim ve Teknoloji Dergisi (2021), 10(2) 92-100

Because maximum liquid yield was taken at $480{ }^{\circ} \mathrm{C}$ and $1 / 5 \mathrm{HAW} / \mathrm{PS}$ ratio, this liquid was analyzed comprehensively. The results were given in Fig.4 and Table 2. As shown in Table 2, the liquid is composed of C5-C14 hydrocarbons mainly. With adding HAW to the feed, the styrene amount decreased to $8.08 \%$ while the ethylbenzene amount increased a little bit. The main component of the liquid was found as naphthalene with a 12.71 percentage of peak area. It has been known that 2-methyl naphthalene which was in liquid with a relatively high amount can be utilized in polyethylenenaphthalate (PEN) production. PEN is a material that can be a rival to polyethylene terephthalate (PET) [22]. Toluene amount decreased with co-pyrolysis compared to PS pyrolysis.

Table 1. Compounds in PS pyrolytic liquid at $480^{\circ} \mathrm{C}$

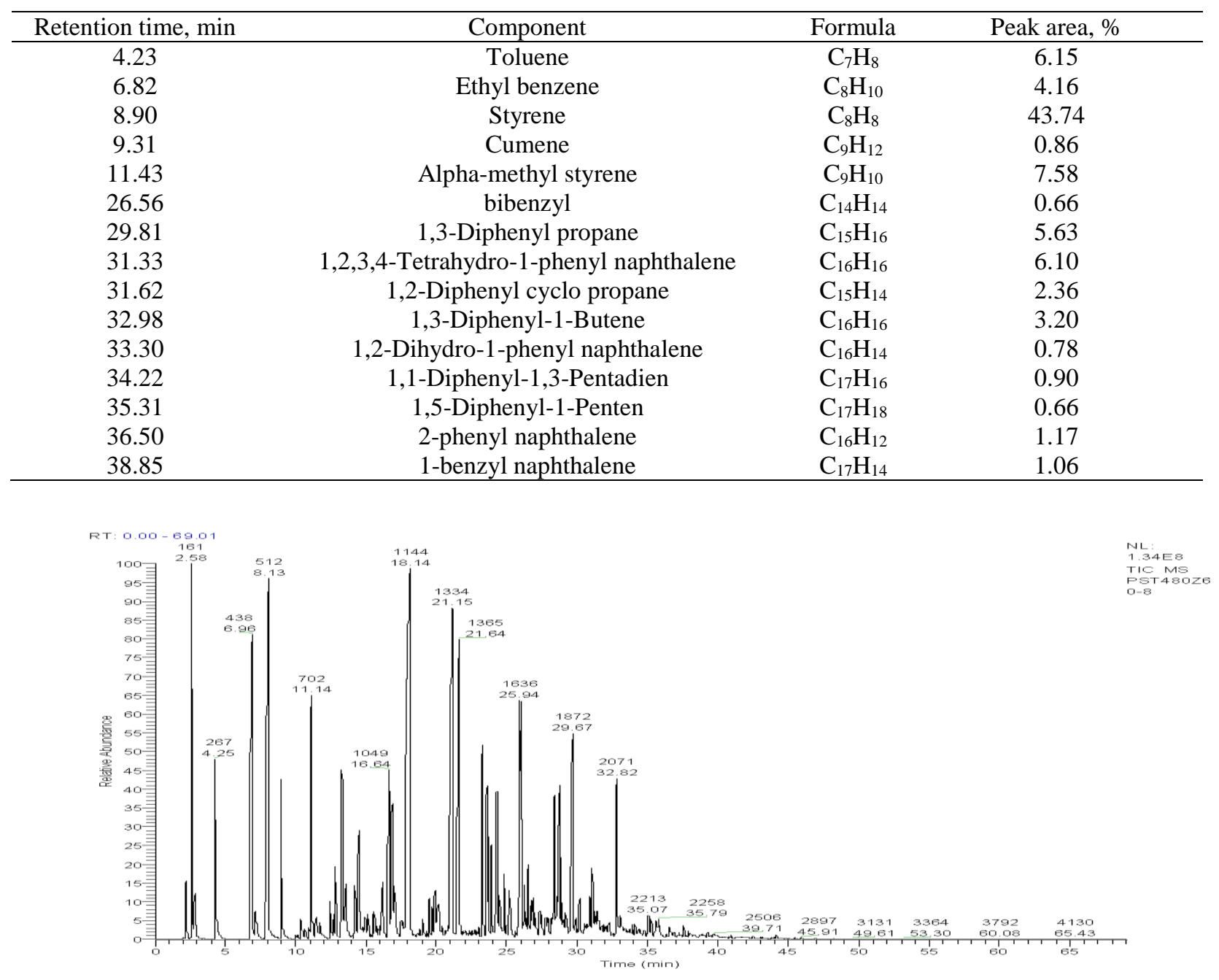

Figure 4. Chromatogram of the liquid product of $1 / 5 \mathrm{HAW} / \mathrm{PS}$ at $480{ }^{\circ} \mathrm{C}$

To see the effect of the HAW/PS ratio and temperature on liquid composition, a group of the component was selected to compare. Detected compounds were given in Fig. 5. At $420^{\circ} \mathrm{C}$, it was observed that naphthalene, 2-methyl naphthalene, and 1-methyl naphthalene yield increased with increasing HAW ratio in feed. However, styrene and alphamethyl styrene yield decreased with this rising. This was an expected situation because naphthalene derivatives and styrene derivatives originated from HAW and PS respectively. It was observed that increasing HAW amount in HAW/PS mixture effect on toluene yield was ignorable. Samely, Shelves et al. determined that adding petroleum waste to the feed did not affect Benzene-Toluene-Xylene yield in the pyrolytic liquid [23]. Maximum ethyl benzene yield was found as $15.88 \%$ in $3 / 5 \mathrm{HAW} / \mathrm{PS}$ ratio at $420{ }^{\circ} \mathrm{C}$. At $450{ }^{\circ} \mathrm{C}$, styrene and alpha-methyl styrene peak area in the liquid was also decreased with increasing HAW in the feed. But if it comes to $480{ }^{\circ} \mathrm{C}$, styrene yield increased while naphthalene yield 
Nevşehir Bilim ve Teknoloji Dergisi (2021), 10(2) 92-100

decreased with HAW adding. Because at high temperatures pyrolysis products of HAW is mainly gaseous compounds like light olefins which don't easily undergo aromatization reactions [23]. This result was commented also on as synergistic interaction between the two feedstock materials. At 1/5 HAW/PS ratio, it was determined that naphthalene, 2-methyl naphthalene, and 1-methyl naphthalene yields increased with increasing temperature (from 420 to $480{ }^{\circ} \mathrm{C}$ ). This situation was clarified that polycyclics converted to the aromatics for petroleum residue [24].

Table 2. Compounds in co-pyrolytic liquid of HAW and PS at $480{ }^{\circ} \mathrm{C}$

\begin{tabular}{|c|c|c|c|}
\hline Retention time, $\min$ & Component & Formula & Peak area, $\%$ \\
\hline 2.21 & 1,3-cyclo pentadien & $\mathrm{C}_{5} \mathrm{H}_{6}$ & 0.51 \\
\hline 4.25 & toluene & $\mathrm{C}_{7} \mathrm{H}_{8}$ & 2.17 \\
\hline 6.96 & Ethyl benzene & $\mathrm{C}_{8} \mathrm{H}_{10}$ & 6.32 \\
\hline 8.13 & styrene & $\mathrm{C}_{8} \mathrm{H}_{8}$ & 8.08 \\
\hline 8.99 & cumene & $\mathrm{C}_{9} \mathrm{H}_{12}$ & 1.47 \\
\hline 11.14 & Alpha-methyl styrene & $\mathrm{C}_{9} \mathrm{H}_{10}$ & 2.84 \\
\hline 12.85 & indane & $\mathrm{C}_{9} \mathrm{H}_{10}$ & 0.69 \\
\hline 13.30 & indene & $\mathrm{C}_{9} \mathrm{H}_{8}$ & 2.05 \\
\hline 13.53 & 2-Ethyl-1,4-Dimethyl Benzene & $\mathrm{C}_{10} \mathrm{H}_{14}$ & 0.56 \\
\hline 16.16 & 2,5-dimethyl styrene & $\mathrm{C}_{10} \mathrm{H}_{12}$ & 0.86 \\
\hline 16.64 & Methyl indene & $\mathrm{C}_{10} \mathrm{H}_{10}$ & 2.48 \\
\hline 16.86 & 1-methyl-4-(1-propenyl) benzene & $\mathrm{C}_{10} \mathrm{H}_{12}$ & 2.37 \\
\hline 18.14 & naphthalene & $\mathrm{C}_{10} \mathrm{H}_{8}$ & 12.71 \\
\hline 20.17 & 1,2-dihydro-6-methyl naphthalene & $\mathrm{C}_{11} \mathrm{H}_{12}$ & 0.8 \\
\hline 21.15 & 2-methyl naphthalene & $\mathrm{C}_{11} \mathrm{H}_{10}$ & 7.3 \\
\hline 21.64 & 1-methyl naphthalene & $\mathrm{C}_{11} \mathrm{H}_{10}$ & 5.31 \\
\hline 23.27 & biphenyl & $\mathrm{C}_{12} \mathrm{H}_{10}$ & 2.08 \\
\hline 23.58 & 2-ethyl naphthalene & $\mathrm{C}_{12} \mathrm{H}_{12}$ & 2.18 \\
\hline 23.89 & 1,6-dimethyl naphthalene & $\mathrm{C}_{12} \mathrm{H}_{12}$ & 0.87 \\
\hline 24.30 & 1,2-dimethyl napthalene & $\mathrm{C}_{12} \mathrm{H}_{12}$ & 2.55 \\
\hline 24.76 & 1,8-dimethyl napthalene & $\mathrm{C}_{12} \mathrm{H}_{12}$ & 0.69 \\
\hline 25.94 & 3-methyl 1,1' biphenyl & $\mathrm{C}_{13} \mathrm{H}_{12}$ & 4.32 \\
\hline 26.51 & Isopropyl naphthalene & $\mathrm{C}_{13} \mathrm{H}_{14}$ & 0.67 \\
\hline 26.84 & 2,3,6-tirimethyl naphthalene & $\mathrm{C}_{13} \mathrm{H}_{14}$ & 0.89 \\
\hline 28.39 & Fluoren & $\mathrm{C}_{13} \mathrm{H}_{10}$ & 1.87 \\
\hline 28.75 & 1,4-dihydro fluoren & $\mathrm{C}_{13} \mathrm{H}_{12}$ & 2.96 \\
\hline 29.67 & 1,3-diphenyl propane & $\mathrm{C}_{15} \mathrm{H}_{16}$ & 2.63 \\
\hline 31.10 & 2-methyl fluorene & $\mathrm{C}_{14} \mathrm{H}_{12}$ & 1.23 \\
\hline 32.82 & anthracene & $\mathrm{C}_{14} \mathrm{H}_{10}$ & 2.28 \\
\hline
\end{tabular}



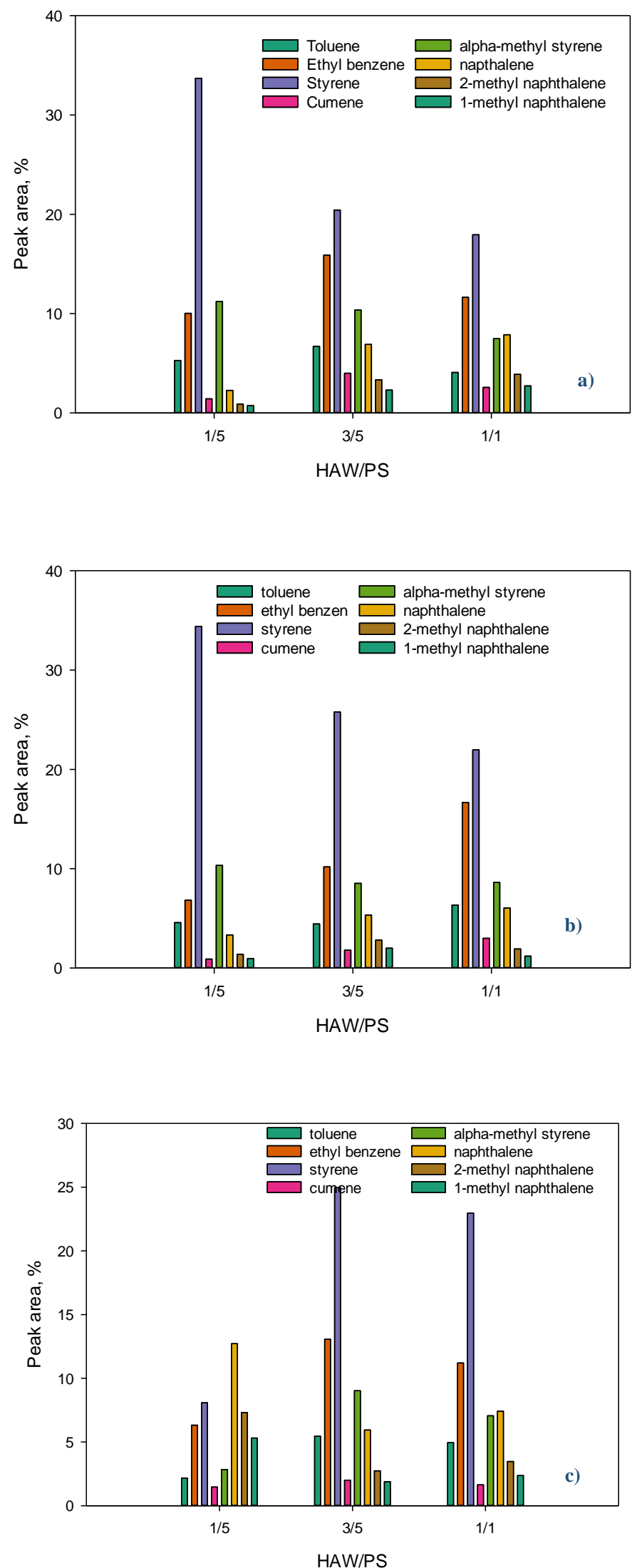

Figure 5. Component distribution of pyrolytic liquid obtained at a) 420 , b) 450 , c) $480{ }^{\circ} \mathrm{C}$ 


\section{Conclusion}

It was performed co-pyrolysis of heavy aromatic waste and polystyrene in a semi-batch glass reactor at 420, 450, $480{ }^{\circ} \mathrm{C}$ with $1 / 5,3 / 5$, and 1/1 HAW/PS weight ratios. Product yields were computed and pyrolytic liquids were detected via GC-MS. Maximum liquid product yield was obtained as $87.24 \%$ at $480{ }^{\circ} \mathrm{C}$ for thermal degradation of HAW/PS (1/5). At that temperature liquid yield of pure PS, pyrolysis was found as $87.02 \%$. Considering that result, it was concluded that liquid yield did not affect HAW adding to the feed. The liquid of HAW/PS (1/5) at $480{ }^{\circ} \mathrm{C}$ is composed of mainly naphthalene derivatives and aromatic hydrocarbons like toluene, ethylbenzene, styrene. The liquid product of polystyrene pyrolysis formed mainly C7-C17 hydrocarbons. However C5-C14 hydrocarbons formed a liquid product of HAW/PS (1/5) at $480{ }^{\circ} \mathrm{C}$. Naphthalene was not found in PS pyrolytic liquid. However, it was observed at the ratio of $12.71 \%$ in HAW/PS $(1 / 5)$ pyrolytic liquid at $480^{\circ} \mathrm{C}$. At $480^{\circ} \mathrm{C}$, styrene yield increased while naphthalene yield decreased with HAW adding. This result was commented as synergistic interaction between the two feedstock materials. Besides that, because of HAW aromatization reactions in high temperatures can not occur easily. At 1/5 HAW/PS ratio, it was determined that increasing temperature affected positively naphthalene, 2-methyl naphthalene, and 1-methyl naphthalene yields. However, at 1/5 HAW/PS ratio, it was observed that increasing temperature affected negatively toluene, ethylbenzene, and alpha-methyl styrene yields. With that study, two waste materials combined to give a valuable hydrocarbon-rich product that can be a fuel.

\section{Contribution of researchers}

In this study; M.A.: as the undergraduate thesis student contributed to do pyrolysis study, analyzing the products, discussing the results, and writing the paper. G.Ö.: as the graduate student contributed to do pyrolysis study, analyze the products, discuss the results and write the paper. A.K.: the supervisor proposed the idea, developed the methodology, and contributed to doing pyrolysis study, analyzing the products, discussing the results, and writing the paper.

\section{References}

[1] Nanda, S., Berruti, F., "Municipal solid waste management and landfilling technologies: a review" Environmental Chemistry Letters, 19(2), 1433-1456, 2021.

[2] The World Bank. https://datatopics.worldbank.org/what-a-waste/trends_in_solid_waste management.html. Date accessed October, 62021.

[3] United States Environmental Protection Agency. https://www.epa.gov/facts-and-figures-about-materials-wasteand-recycling/national-overview-facts-and-figures-materials. Date accessed October 6, 2021.

[4] Siddique, R., Khatib, J., Kaur, I., "Use of recycled plastic in concrete: A review" Waste management, 28(10), 1835-1852, 2008.

[5] Özçakır, G., Karaduman, A., "Chemical recovery from polystyrene waste and low density polyethylene via conventional pyrolysis” Eskişehir Osmangazi Üniversitesi Mühendislik ve Mimarlık Fakültesi Dergisi, 28(2), $155-163,2020$.

[6] Nanda, S., Berruti, F., "Thermochemical conversion of plastic waste to fuels: a review" Environmental Chemistry Letters, 19(1), 123-148, 2021.

[7] Karaduman, A., Şimşek, E. H., Cicek, B., Bilgesü, A. Y., "Flash pyrolysis of polystyrene wastes in a free-fall reactor under vacuum" Journal of Analytical and Applied Pyrolysis, 60(2), 179-186, 2001.

[8] Nisar, J., Ali, G., Shah, A., Iqbal, M., Khan, R. A., Anwar, F., Akhter, M. S., "Fuel production from waste polystyrene via pyrolysis: Kinetics and products distribution” Waste management, 88, 236-247, 2019. 
Nevşehir Bilim ve Teknoloji Dergisi (2021), 10(2) 92-100

[9] Park, K. B., Jeong, Y. S., Guzelciftci, B., Kim, J. S., “Two-stage pyrolysis of polystyrene: Pyrolysis oil as a source of fuels or benzene, toluene, ethylbenzene, and xylenes” Applied Energy, 259, 114240, 2020.

[10] Wu, Y., Zhu, J., Zhao, S., Wang, D., Jin, L., Hu, H., “Co-pyrolysis behaviors of low-rank coal and polystyrene with in-situ pyrolysis time-of-flight mass spectrometry” Fuel, 286, 119461, 2021.

[11] Burra, K. R. G., Liu, X., Wang, Z., Li, J., Che, D., Gupta, A. K., "Quantifying the sources of synergistic effects in co-pyrolysis of pinewood and polystyrene" Applied Energy, 302, 117562, 2021.

[12] Stančin, H., Šafár̆, M., Růžičková, J., Mikulčić, H., Raclavská, H., Wang, X., Duić, N., “Co-pyrolysis and synergistic effect analysis of biomass sawdust and polystyrene mixtures for production of high-quality bio-oils" Process Safety and Environmental Protection, 145, 1-11, 2021.

[13] Sanahuja-Parejo, O., Veses, A., Navarro, M. V., López, J. M., Murillo, R., Callén, M. S., García, T., “Drop-in biofuels from the co-pyrolysis of grape seeds and polystyrene" Chemical Engineering Journal, 377, 120246, 2019.

[14] Kositkanawuth, K., Bhatt, A., Sattler, M., Dennis, B., "Renewable energy from waste: investigation of copyrolysis between sargassum macroalgae and polystyrene" Energy \& Fuels, 31(5), 5088-5096, 2017.

[15] Reshad, A. S., Tiwari, P., \& Goud, V. V., "Thermal and co-pyrolysis of rubber seed cake with waste polystyrene for bio-oil production” Journal of Analytical and Applied Pyrolysis, 139, 333-343, 2019.

[16] Van Nguyen, Q., Choi, Y. S., Choi, S. K., Jeong, Y. W., Han, S. Y., “Co-pyrolysis of coffee-grounds and waste polystyrene foam: Synergistic effect and product characteristics analysis” Fuel, 292, 120375, 2021.

[17] Odejobi, O. J., Oladunni, A. A., Sonibare, J. A., Abegunrin, I. O., "Oil yield optimization from co-pyrolysis of low-density polyethylene (LDPE), polystyrene (PS) and polyethylene terephthalate (PET) using simplex lattice mixture design" Fuel Communications, 2, 100006, 2020.

[18] Hui, K., Tang, J., Lu, H., Xi, B., Qu, C., Li, J., "Status and prospect of oil recovery from oily sludge: A review" Arabian Journal of Chemistry, 13(8), 6523-6543, 2020.

[19] Hu, G., Li, J., Zeng, G., "Recent development in the treatment of oily sludge from petroleum industry: a review" Journal of hazardous materials, 261, 470-490, 2013.

[20] Li, J., Lin, F., Li, K., Zheng, F., Yan, B., Che, L., Yoshikawa, K., “A critical review on energy recovery and non-hazardous disposal of oily sludge from petroleum industry by pyrolysis" Journal of Hazardous Materials, 406, 124706, 2021.

[21] Senneca, O., Chirone, R., Cortese, L., Salatino, P., "Pyrolysis and combustion of a solid refinery waste" Fuel, 267, 117258, 2020.

[22] Güleç, F., Sher, F., Karaduman, A., "Catalytic performance of Cu-and Zr-modified beta zeolite catalysts in the methylation of 2-methylnaphthalene" Petroleum Science, 16(1), 161-172, 2019.

[23] Suelves, I., Moliner, R., Lazaro, M. J., "Synergetic effects in the co-pyrolysis of coal and petroleum residues: influences of coal mineral matter and petroleum residue mass ratio" Journal of Analytical and Applied Pyrolysis, 55(1), 29-41, 2000.

[24] Ma, Z., Xie, J., Gao, N., Quan, C., "Pyrolysis behaviors of oilfield sludge based on Py-GC/MS and DAEM kinetics analysis” Journal of the Energy Institute, 92(4), 1053-1063, 2019. 